\title{
Nitric oxide counteracts the senescence of rice leaves induced by abscisic acid
}

\author{
Kuo Tung Hung, Ching Huei Kao* \\ Department of Agronomy, National Taiwan University, Taipei, Taiwan, Republic of China
}

Received December 4, 2002 - Accepted March 13, 2003

\begin{abstract}
Summary
In the present study, we evaluate the protective effect of nitric oxide (NO) against senescence of rice leaves promoted by ABA. Senescence of rice leaves was determined by the decrease of protein content. ABA treatment resulted in (1) induction of leaf senescence, (2) increase in $\mathrm{H}_{2} \mathrm{O}_{2}$ and malondialdehyde (MDA) contents, (3) decrease in reduced form glutathione (GSH) and ascorbic acid (AsA) contents, and (4) increase in antioxidative enzyme activities (superoxide dismutase, ascorbate peroxidase, glutathione reductase, and catalase). All these ABA effects were reduced by free radical scavengers such as sodium benzoate and GSH. NO donors [ $\mathrm{N}$-tert-butyl- $\alpha$-phenylnitrone (PBN), sodium nitroprusside, 3-morpholinosydonimine, and $\mathrm{As} A+\mathrm{NaNO}_{2}$ ] were effective in reducing ABAinduced leaf senescence. PBN prevented ABA-induced increase in the contents of $\mathrm{H}_{2} \mathrm{O}_{2}$ and MDA, decrease in the contents of GSH and AsA, and increase in the activities of antioxidative enzymes. The protective effect of PBN on ABA-promoted senescence, ABA-increased $\mathrm{H}_{2} \mathrm{O}_{2}$ content and lipid peroxidation, $\mathrm{ABA}$-decreased $\mathrm{GSH}$ and $\mathrm{As} \mathrm{A}$, and $\mathrm{ABA}$-increased antioxidative enzyme activities was reversed by 2-(4-carboxy-2-phenyl)-4,4,5,5-tetramethylimidazoline-1-oxyl-3-oxide, a NO-specific scavenger, suggesting that the protective effect of PBN is attributable to NO released. Reduction of ABA-induced senescence by $\mathrm{NO}$ in rice leaves is most likely mediated through its ability to scavenge active oxygen species including $\mathrm{H}_{2} \mathrm{O}_{2}$.
\end{abstract}

Key words: abscisic acid - active oxygen species - lipid peroxidation - nitric oxide - Oryza sativa

Abbreviations: $A O S=$ active oxygen species. - APOD $=$ ascorbate peroxidase. - AsA $=$ ascorbic acid. - CAT $=$ catalase. - c-PTIO = 2-(4-carboxy-2-phenyl)-4,4,5,5-tetramethylimidazoline-1-oxyl-3oxide. - ELISA = enzyme-linked immunosorbent assay. $-\mathrm{FW}=$ fresh weight. $-\mathrm{GR}=$ glutathione reductase. $-\mathrm{GSH}=$ reduced glutathione. $-\mathrm{MDA}=$ malondialdehyde. $-\mathrm{NO}=$ nitric oxide. $-\mathrm{PBN}=$ $\mathrm{N}$-tert-butyl- $\alpha$-phenylnitrone. $-\mathrm{POD}=$ peroxidase. $-\mathrm{SB}=$ sodium benzoate. $-\mathrm{SIN}-1=3$-morpholinosydonimine. - SNP = sodium nitroprusside. - SOD = superoxide dismutase

\footnotetext{
* E-mail corresponding author: kaoch@ccms.ntu.edu.tw
} 


\section{Introduction}

The plant hormone ABA is a sesquiterpenoid synthesized from xanthophylls (Creelman 1989, Taylor et al. 2000, Seo and Koshiba 2002) and appears to influence several physiological and developmental events (Creelman 1989, Kende and Zeevaart 1997). It has been suggested that $A B A$ is one of the most effective plant hormones in terms of promoting leaf senescence (Nooden 1988). Applied ABA has been found to promote leaf senescence in a wide range of plant species (Nooden 1988, Creelman 1989). An increase in endogenous ABA has been shown to coincide with senescence of leaves (Gepstein and Thimann 1980, Yang et al. 2002).

Lipid peroxidation is considered to be an important mechanism of leaf senescence (Thompson et al. 1987, Strother 1988). Active oxygen species (AOS) can initiate lipid peroxidation (Kellogg and Fridovich 1975). It has been shown that ABA causes generation of AOS including $\mathrm{H}_{2} \mathrm{O}_{2}$ (Guan et al. 2000, Pei et al. 2000, Jiang and Zhang 2001) and lipid peroxidation expressed as malondialdehyde (MDA) production in plant cells (Bueno et al. 1998). Thus, ABA leads to an oxidative stress in plant cells.

Nitric oxide (NO) is a free radical gas with well-characterized signaling roles in mammalian systems, acting as a second messenger during vasorelaxation, neurotransmission, immunity, and cytotoxicity (Furchgott 1995). It is now evident NO plays essential roles in animal physiology. In contrast to the large body of knowledge regarding NO in animal cells, the physiology and biochemistry of NO in plants is less well understood. There are an increasing number of reports indicating that NO could also participate in many physiological responses of plants: pathogen response (Delledonne et al 1998, Klessig et al. 2000), programmed cell death (Pedroso et al. 2000, Beligni et al. 2002), growth (Leshem and Haramaty 1996), germination (Beligni and Lamattina 2000), root organogenesis (Pagnussat et al. 2002), phytoalexin production (Noritake et al. 1996), cytokinin action (Scherer and Holk 2000), ABA-dependent stomatal closure (Garcia-Mata and Lamattina 2002, Neill et al. 2002), and ethylene emission (Leshem 2000).

Several reports convincingly demonstrate that NO is able to counteract the toxicity of paraquat and diquat, which are known to generate AOS, in potato and rice leaves (Beligni and Lamattina 1999 a, b, Hung et al. 2002). Recently, Beligni and Lamattina (2002) provided strong evidence that NO interferes with plant photo-oxidative stress by detoxifying AOS. Thus, a possible participation of $\mathrm{NO}$ in antioxidant system in plants, as it does in animals (O'Donnell et al. 1997, d'Ischia et al. 2000), is suggested. In rice leaves, it has been shown that $\mathrm{NO}$ donors reduced paraquat toxicity through decrease in lipid peroxidation (Hung et al. 2002). More recently, we showed that the promotion of rice leaf senescence caused by polyethylene glycol and dehydration, which induce lipid peroxidation, can be counteracted by NO donors, but the senescence caused by sorbitol, which has no effect on lipid peroxi- dation, cannot be counteracted by NO donors (Cheng et al. 2002). In the present investigation, we examined the effect of $\mathrm{NO}$ on ABA-promoted senescence of rice leaves.

\section{Materials and Methods}

\section{Plant material and chemicals}

Rice (Oryza sativa L., cv. Taichung Native 1) was sterilized with $2.5 \%$ sodium hypochlorite for $15 \mathrm{~min}$ and washed extensively with distilled water. These seeds were then germinated in Petri dishes with wetted filter paper at $37^{\circ} \mathrm{C}$ under dark condition. After $48 \mathrm{~h}$ incubation, uniformly germinated seeds were selected and cultivated in a $500 \mathrm{~mL}$ beaker containing half-strength Kimura B solution as described previously (Chu and Lee 1989). The hydroponically cultivated seedlings were grown for 12 days in a Phytotron with natural light $30^{\circ} \mathrm{C}$ day $(12 \mathrm{~h}) / 25^{\circ} \mathrm{C}$ night $(12 \mathrm{~h})$ and $90 \%$ relative humidity. The apical $3 \mathrm{~cm}$ of the third leaf was used in all experiments. A group of ten segments was floated in a Petri dish containing $10 \mathrm{~mL}$ of test solution. Incubation was carried out at $27^{\circ} \mathrm{C}$ in the dark.

Test solutions included ABA, NO donors, a NO scavenger (cPTIO), and free radical scavengers. PBN, SIN-1 and SNP were used as NO donors. We also used a solution containing ascorbic acid and $\mathrm{NaNO}_{2}$ as another NO donor. Sodium benzoate (SB) and GSH were used as free radical scavengers. All chemicals were purchased from Sigma Co. (St. Louis, MO, USA)

\section{Determinations of protein, $\mathrm{H}_{2} \mathrm{O}_{2}$, lipid peroxidation, $\mathrm{GSH}$, and AsA}

The senescence of detached rice leaves was followed by measuring the decrease of protein content. For protein extraction, leaf segments were homogenized in $50 \mathrm{mmol} \mathrm{L}^{-1}$ sodium phosphate buffer ( $\mathrm{pH} 6.8$ ). The extracts were centrifuged at $17,600 \mathrm{~g}_{\mathrm{n}}$ for $20 \mathrm{~min}$, and the supernatants were used for determination of protein by the method of Bradford (1976) and enzyme activities. The $\mathrm{H}_{2} \mathrm{O}_{2}$ content was measured colorimetrically as described by Jana and Choudhuri (1981). $\mathrm{H}_{2} \mathrm{O}_{2}$ was extracted by homogenizing leaf tissue with phosphate buffer (50 mmol L $\left.{ }^{-1}, \mathrm{pH} 6.5\right)$ containing $1 \mathrm{mmol} \mathrm{L}^{-1}$ hydroxylamine. The homogenate was centrifuged at $6,000 \mathrm{~g}_{\mathrm{n}}$ for $25 \mathrm{~min}$. To determine $\mathrm{H}_{2} \mathrm{O}_{2}$ content, extracted solution was mixed with $0.1 \%$ titanium sulphate in $20 \%$ ( $v / v) \mathrm{H}_{2} \mathrm{SO}_{4}$. The mixture was then centrifuged at $6,000 \mathrm{~g}_{\mathrm{n}}$ for $25 \mathrm{~min}$. The absorbance was measured at $410 \mathrm{~nm}$. The $\mathrm{H}_{2} \mathrm{O}_{2}$ content was calculated using the extinction coefficient $0.28 \mu \mathrm{mol}^{-1} \mathrm{~cm}^{-1}$. MDA, routinely used as an indicator of lipid peroxidation, was extracted with $5 \%(w / v)$ trichloroacetic acid and determined according Heath and Packer (1968). GSH in $3 \%$ sulfosalicylic acid extract and AsA in $5 \%$ $(\mathrm{w} / \mathrm{v})$ trichloroacetic acid extract were determined as described by Smith (1985) and Laws et al. (1983), respectively.

\section{Enzyme assays}

Peroxidase (POD) activity was measured using a modification of the procedure of MacAdam et al. (1992). Activity was calculated using the extinction coefficient [26.6 ( $\left.\mathrm{mmol} \mathrm{L}^{-1}\right)^{-1} \mathrm{~cm}^{-1}$ at $470 \mathrm{~nm}$ ] for tetraguaiacol. Catalase (CAT) activity was assayed by measuring the initial rate of disappearance of $\mathrm{H}_{2} \mathrm{O}_{2}$ (Kato and Shimizu 1987). The decrease in 
$\mathrm{H}_{2} \mathrm{O}_{2}$ was followed as the decline in absorbance at $240 \mathrm{~nm}$, and activity was calculated using the extinction coefficient $\left[40\left(\mathrm{mmol} \mathrm{L}^{-1}\right)^{-1}\right.$ $\mathrm{cm}^{-1}$ at $240 \mathrm{~nm}$ ] for $\mathrm{H}_{2} \mathrm{O}_{2}$ (Kato and Shimizu 1987). Superoxide dismutase (SOD) was determined according to Paoletti et al. (1986). APOD was determined according to Nakano and Asada (1981). The decrease in AsA concentration was followed as the decline in optical density at $290 \mathrm{~nm}$ and activity was calculated using the extinction coefficient [2.8 $\left(\mathrm{mmol} \mathrm{L}^{-1}\right)^{-1} \mathrm{~cm}^{-1}$ at $290 \mathrm{~nm}$ ] for AsA. Glutathione reductase (GR) was determined by the method of Foster and Hess (1980). One unit of activity for CAT, POD, SOD, APOD, and GR was defined as the amount of enzyme which degraded $1 \mu \mathrm{mol} \mathrm{H}_{2} \mathrm{O}_{2}$ per min, caused the formation of $1 \mu \mathrm{mol}$ tetraguaiacol per min, inhibited $50 \%$ the rate of $\mathrm{NADH}$ oxidation observed in control, degraded $1 \mu \mathrm{mol}$ of AsA per min, and decreased $1 A_{340}$ per min, respectively.

\section{ABA assay}

For extraction of abscisic acid (ABA), leaf samples were homogenized with a motor and pestle in extraction solution $(80 \%$ methano containing $2 \%$ glacial acetic acid). To remove plant pigments and other non-polar compounds which could interfere in the immunoassay, extracts were first passed through polyvinylpyrrolidone column and $\mathrm{C}_{18}$ cartridges. The eluates were concentrated to dryness by vacuum-evaporation and resuspended in Tris-buffered saline before enzyme-linked immunosorbent assay (ELISA). ABA was quantitated by ELISA (Walker-Simmons 1987). ABA immunoassay detection kit
(PGR-1) was purchased from Sigma Chemical Co. (St Louis MO, USA), is specific for (+)-ABA. By evaluating ${ }^{3} \mathrm{H}$-ABA recovery, ABA loss was less than $3 \%$ by the method described here.

\section{Experimental design}

Protein, $\mathrm{H}_{2} \mathrm{O}_{2}, \mathrm{MDA}, \mathrm{AsA}, \mathrm{GSH}$, and ABA contents were expressed per $g$ fresh weight (FW). Enzyme activities were expressed as unit $\mathrm{mg}^{-1}$ protein. In the present investigation, rice seedlings were grown for 12 days in a greenhouse, where natural light was provided. The growth of rice seedlings is very sensitive to light and varies with different light intensities. Experiments were carried out at different times of the year. Thus, absolute levels of each measurement varied among experiments because of seasonal effects. However, the patterns of response to ABA and/or NO donors were reproducible. All measurements described here were repeated three times. Similar results and identical trends were obtained each time. The data reported here are from a single experiment.

\section{Results}

The obvious character of leaf senescence is yellowing. Chlorophyll loss has been the principal criterion of senescence for the largest number of workers. The protein break-
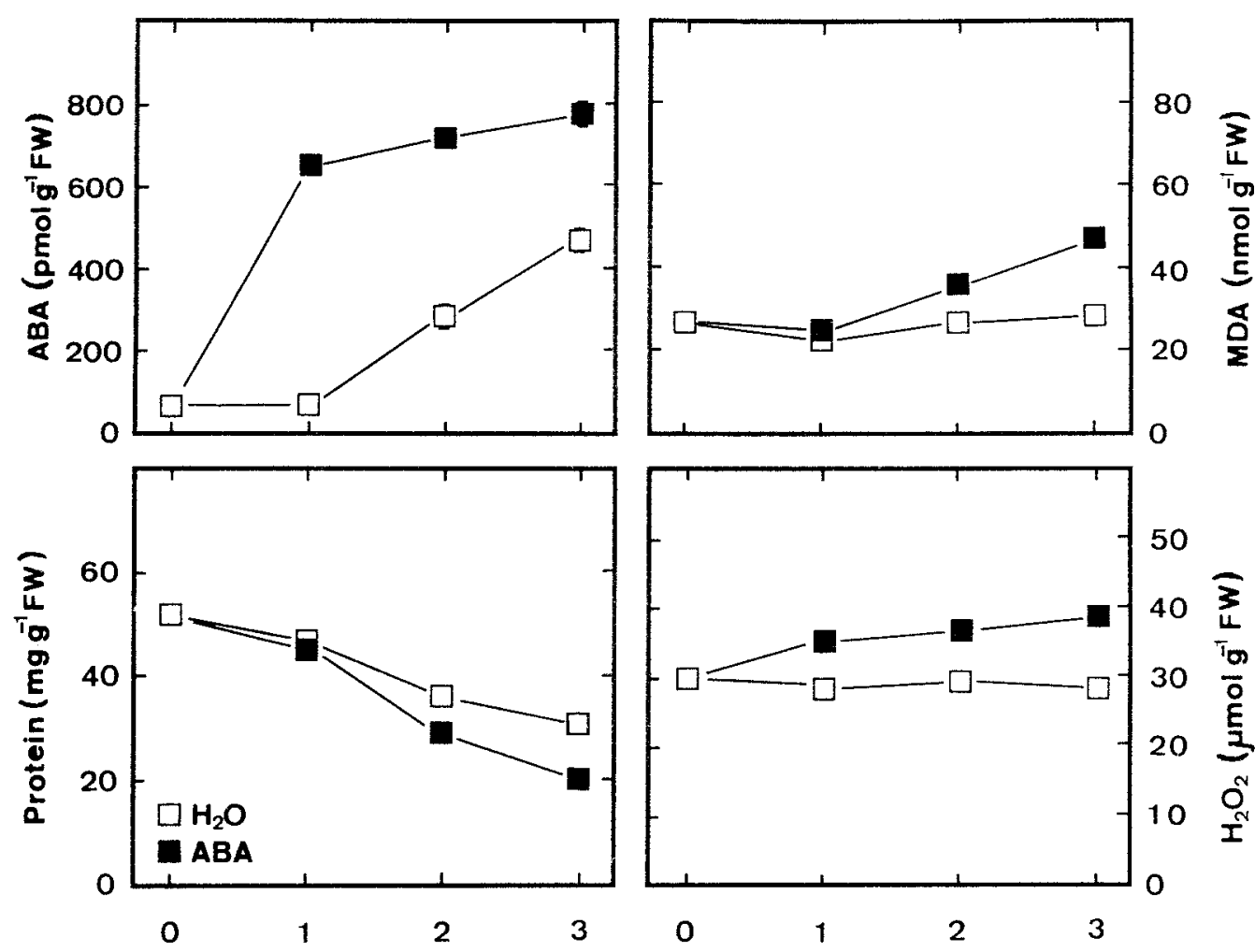

Time (d)

Figure 1. Changes in the contents of $A B A$, protein, $M D A$, and $\mathrm{H}_{2} \mathrm{O}_{2}$ in rice leaves treated with $A B A$. Detached rice leaves were treated with either water or $45 \mu \mathrm{mol} \mathrm{L}{ }^{-1} \mathrm{ABA}$ in the dark. Data are means $( \pm \mathrm{SE})$ of four replicates of a single typical experiment. Three series of independent experiments were carried out giving reproducible results. 
Table 1. Effect of free radical scavengers (SB and GSH) on protein, $\mathrm{MDA}$, and $\mathrm{H}_{2} \mathrm{O}_{2}$ contents in rice leaves treated with $\mathrm{ABA}$.

\begin{tabular}{llll}
\hline Treatment & $\begin{array}{l}\text { Protein } \\
\left(\mathrm{mg} \mathrm{g}^{-1} \mathrm{FW}\right)\end{array}$ & $\begin{array}{l}\mathrm{MDA} \\
\left(\mathrm{nmol} \mathrm{g}^{-1} \mathrm{FW}\right)\end{array}$ & $\begin{array}{l}\mathrm{H}_{2} \mathrm{O}_{2} \\
(\mu \mathrm{mol} \mathrm{g}\end{array}$ \\
\hline $\mathrm{H}_{2} \mathrm{O}$ & $33.7 \pm 0.32$ & $33.6 \pm 0.55$ & $29.0 \pm 1.3$ \\
$\mathrm{ABA}$ & $22.1 \pm 0.70$ & $53.2 \pm 1.2$ & $38.6 \pm 0.92$ \\
$\mathrm{ABA}+\mathrm{SB}$ & $27.7 \pm 0.21$ & $37.5 \pm 2.6$ & $30.0 \pm 0.55$ \\
$\mathrm{ABA}+\mathrm{GSH}$ & $26.3 \pm 1.1$ & $35.6 \pm 1.8$ & $29.2 \pm 0.68$ \\
\hline
\end{tabular}

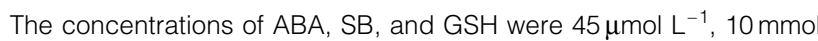
$\mathrm{L}^{-1}$, and $30 \mathrm{mmol} \mathrm{L}^{-1}$, respectively. Protein, MDA, and $\mathrm{H}_{2} \mathrm{O}_{2}$ were determined 3 days after treatment in the dark. Data are means ( \pm SE) of four replicates of a single typical experiment. Three series of independent experiments were carried out giving reproducible results.

down during leaf senescence has been realized from earliest studies. We have shown that protein breakdown precedes chlorophyll loss during rice leaf senescence (Kao 1980). Thus, senescence of rice leaves in the present investigation was followed by measuring the decrease of protein. The changes in protein and MDA contents in detached rice leaves treated with $45 \mu \mathrm{mol} / \mathrm{L}$ ABA in the dark are shown in Figure 1. The decease in protein and increase in MDA was evident at 2 days after $A B A$ treatment. Clearly, ABA is effective in promoting senescence of rice leaves. $A B A$ treatment resulted in a marked increase in MDA, indicating that $A B A$ brings about lipid peroxidation. Lipid peroxidation is caused by AOS (Kellogg and Fridovich 1975, Thompson et al. 1987). ABA treatment also caused an increase in $\mathrm{H}_{2} \mathrm{O}_{2}$ content (Fig. 1). The increase in $\mathrm{H}_{2} \mathrm{O}_{2}$ was evident at 1 day after ABA treatment, which preceded the decrease in protein and increase in MDA. In the present investigation, when free radical scavengers such as SB and GSH, were used together with ABA, it was found that they partially inhibited the reduction in protein content and the increase in MDA and $\mathrm{H}_{2} \mathrm{O}_{2}$ contents caused by ABA (Table 1). These results support the involvement of AOS as the chemical species inducing ABA-enhanced senescence in rice leaves.

Figure 1 also shows the changes in endogenous ABA content in detached rice leaves treated with $45 \mu \mathrm{mol} \mathrm{L}^{-1} \mathrm{ABA}$. As expected, ABA-treated leaves had higher endogenous ABA content than $\mathrm{H}_{2} \mathrm{O}$-treated leaves. In $\mathrm{H}_{2} \mathrm{O}$-treated rice leaves, endogenous ABA content increased at 2 days after dark incubation and protein loss occurred at one day after dark in-

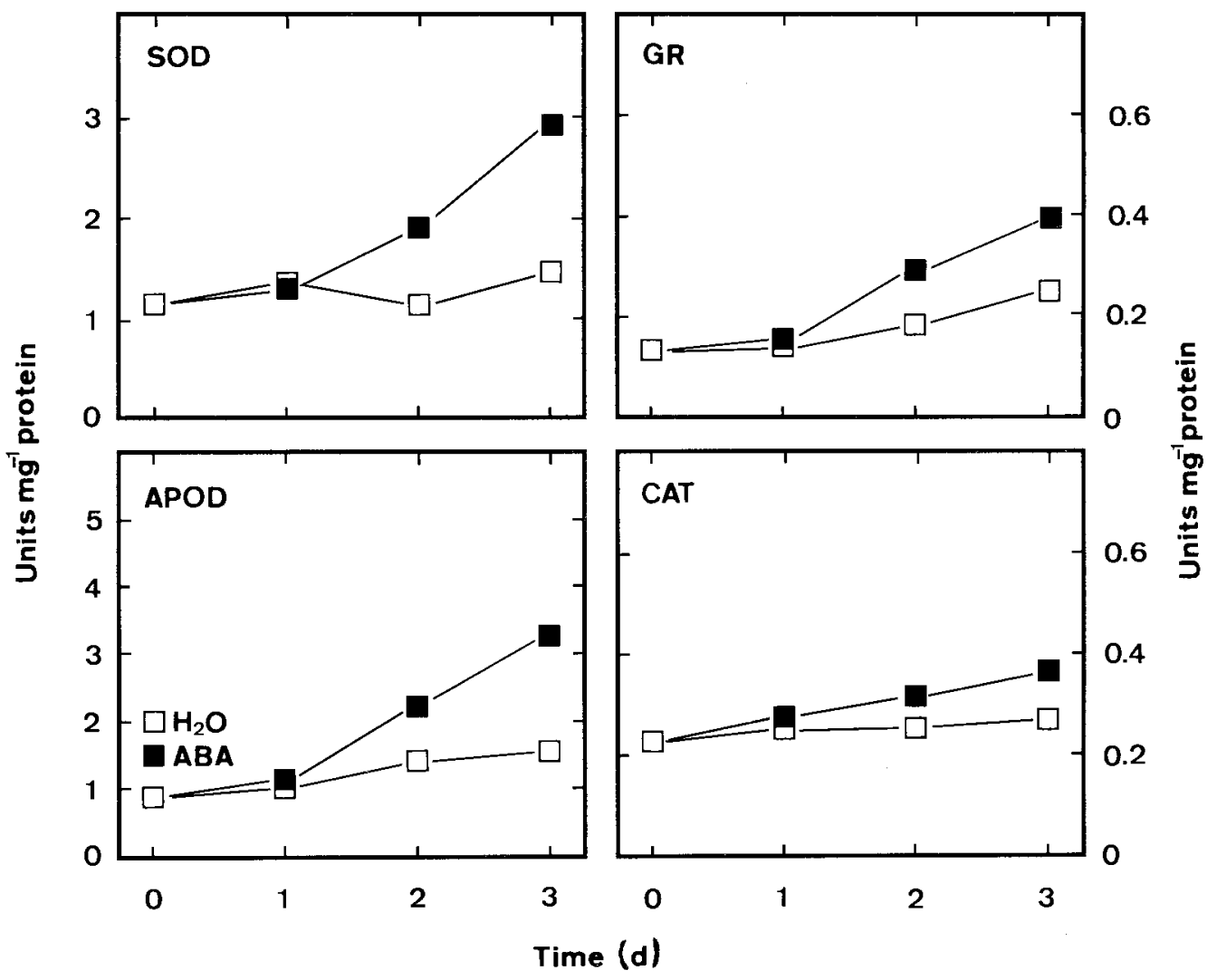

Figure 2. Changes in the activities of SOD, APOD, GR, and CAT in rice leaves treated with ABA. Detached rice leaves were treated with either water or $45 \mu \mathrm{mol} \mathrm{L}^{-1} \mathrm{ABA}$ in the dark. Data are means $( \pm \mathrm{SE}$ ) of four replicates of a single typical experiment. Three series of independent experiments were carried out giving reproducible results. 

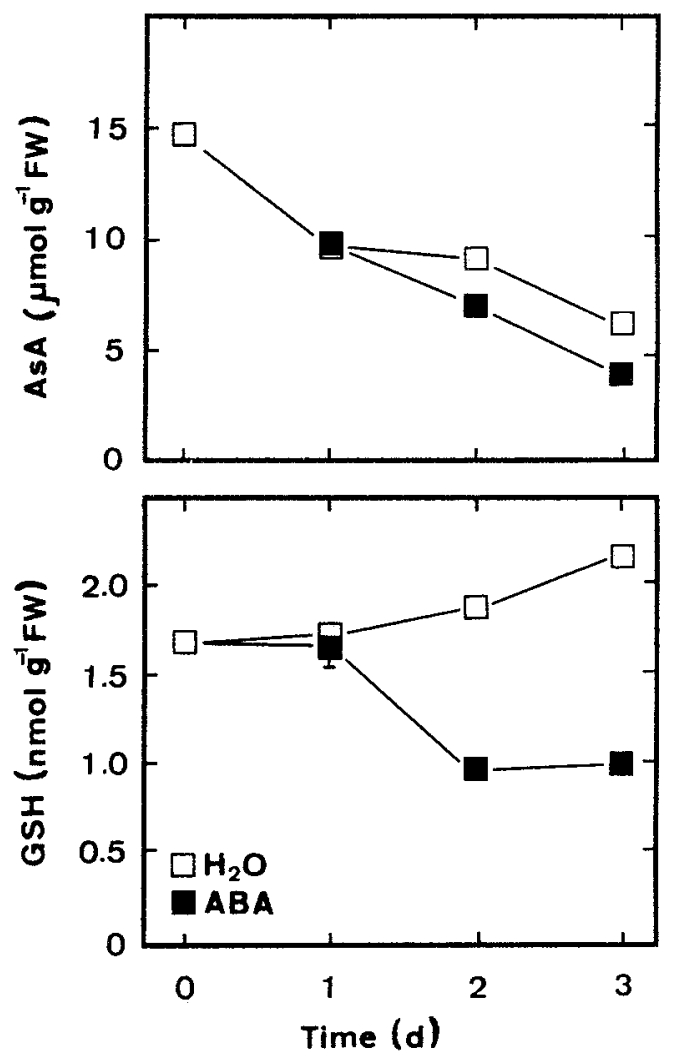

Figure 3. Changes in the contents of AsA and GSH in rice leaves treated with $A B A$. Detached rice leaves were treated with either water or $45 \mu \mathrm{mol} \mathrm{L}{ }^{-1} \mathrm{ABA}$ in the dark. Data are means ( $\pm \mathrm{SE}$ ) of four replicates of a single typical experiment. Three series of independent experiments were carried out giving reproducible results.

cubation, indicating that endogenous ABA does not play a primary role in the regulation of dark-induced senescence of rice leaves, although exogenous application of ABA promoted senescence of rice leaves (Fig. 1). Figure 1 also show that no changes in MDA and $\mathrm{H}_{2} \mathrm{O}_{2}$ contents were observed in control leaves. It appears that there is no direct relationship between lipid peroxidation and dark induced senescence of rice leaves.

Plant cells are equipped with several AOS detoxifying enzymes and antioxidants to protect them against oxidative damage. Antioxidative enzymes include SOD, APOD, GR, CAT, and POD (Foyer et al. 1997). AsA and GSH are two main water-soluble antioxidants (Foyer et al. 1997). The striking increase in lipid peroxidation seen in rice leaves treated with ABA may be a reflection of the change of the activities of antioxidative enzymes and the contents of antioxidants. As shown in Fig. 2, ABA-treated rice leaves had higher activities of SOD, APOD, GR, and CAT than the controls (Fig. 2). But ABA treatment had no effect on POD activity in rice leaves (data not shown). Treatment with ABA significantly decreased AsA and GSH contents compared with the control leaves, it occurred at 2 days after treatment (Fig. 3). The increased activities of antioxidative enzymes and the decreased contents of AsA and GSH in response to ABA are further suggesting of strong induction of oxidative stress. As expected, treatment with free radical scavengers (SB and GSH) inhibited the increase in the activities of antioxidative enzymes and the decrease in the contents of AsA and GSH in rice leaves caused by ABA (Table 2).

Here we show that the promotion of senescence of detached rice leaves by ABA is linked to lipid peroxidation or oxidative stress. NO is known to counteract oxidative stress in plants (Beligni and Lamattina 1999 a, b, 2002, Beligni et al 2002, Cheng et al. 2002, Hung et al. 2002). Thus, it is of great interest to know whether the protective role of $\mathrm{NO}$ is also active in ABA-promoted senescence of rice leaves. Consequently, detached rice leaves were treated with $A B A$ in the presence or absence of $\mathrm{NO}$ donors, such as PBN, SIN-1, SNP, and a mixture of AsA and $\mathrm{NaNO}_{2}$ in the dark. As indicated in Table 3, all NO donors were effective in inhibiting ABA-promoted senescence of rice leaves.

PBN alone had no effect on protein content (Fig. 4). When applied together with ABA, PBN concentrations between 25 and $200 \mu \mathrm{mol} / \mathrm{L}$ produced a clear protection against protein loss (Fig. 4). The optimal concentration of PBN in inhibiting

Table 2. Effect of free radical scavengers on the activities of antioxidative enzymes (CAT, SOD, APOD, and GR) and the contents of AsA and GSH in rice leaves treated with $A B A$.

\begin{tabular}{llllllr}
\hline Treatment & $\begin{array}{l}\text { CAT } \\
\text { (units } \mathrm{mg}^{-1} \text { protein) }\end{array}$ & $\begin{array}{l}\text { SOD } \\
\text { (units } \mathrm{mg}^{-1} \text { protein) }\end{array}$ & $\begin{array}{l}\text { APOD } \\
\text { (units } \mathrm{mg}^{-1} \text { protein) }\end{array}$ & $\begin{array}{l}\text { GR } \\
\text { (units } \mathrm{mg}^{-1} \text { protein) }\end{array}$ & $\begin{array}{l}\text { AsA } \\
\left(\mu \mathrm{mol} \mathrm{g}^{-1} \mathrm{FW}\right)\end{array}$ & $\begin{array}{l}\mathrm{GSH} \\
\left(\mathrm{nmol} \mathrm{g}{ }^{-1} \mathrm{FW}\right)\end{array}$ \\
\hline $\mathrm{H}_{2} \mathrm{O}$ & $0.18 \pm 0.02$ & $1.2 \pm 0.06$ & $1.1 \pm 0.04$ & $0.17 \pm 0.01$ & $7.6 \pm 0.27$ & $2.2 \pm 0.05$ \\
$\mathrm{ABA}$ & $0.29 \pm 0.04$ & $2.8 \pm 0.10$ & $3.0 \pm 0.12$ & $0.33 \pm 0.02$ & $5.7 \pm 0.18$ & $1.0 \pm 0.08$ \\
$\mathrm{ABA}+\mathrm{SB}$ & $0.22 \pm 0.01$ & $2.2 \pm 0.07$ & $1.9 \pm 0.07$ & $0.26 \pm 0.02$ & $6.8 \pm 0.23$ & $2.6 \pm 0.05$ \\
$\mathrm{ABA}+\mathrm{GSH}$ & $0.21 \pm 0.01$ & $1.8 \pm 0.10$ & $1.8 \pm 0.03$ & $0.26 \pm 0.01$ & $9.1 \pm 0.13$ & $11.0 \pm 0.69$ \\
\hline
\end{tabular}

The concentrations of $\mathrm{ABA}, \mathrm{SB}$, and GSH were $45 \mu \mathrm{mol} \mathrm{L}-1,10 \mathrm{mmol} \mathrm{L}^{-1}$, and $30 \mathrm{mmol} \mathrm{L}^{-1}$, respectively. All measurements were determined 3 days after treatment in the dark. Data are means $( \pm S E)$ of four replicates of a single typical experiment. Three series of independent experiments were carried out giving reproducible results. 
Table 3. Effect of NO donors on protein content in rice leaves treated with ABA.

\begin{tabular}{ll}
\hline Treatment & Protein $\left(\mathrm{mg} \mathrm{g}^{-1} \mathrm{FW}\right)$ \\
\hline $\mathrm{H}_{2} \mathrm{O}$ & $40.2 \pm 1.1$ \\
$\mathrm{ABA}$ & $28.7 \pm 0.51$ \\
$\mathrm{ABA}+\mathrm{PBN}$ & $31.9 \pm 0.64$ \\
$\mathrm{ABA}+\mathrm{SIN}-1$ & $30.5 \pm 1.1$ \\
$\mathrm{ABA}+\mathrm{SNP}$ & $31.8 \pm 1.2$ \\
$\mathrm{ABA}+\mathrm{AsA}+\mathrm{NaNO}_{2}$ & $33.8 \pm 1.9$ \\
\hline
\end{tabular}

The concentrations of ABA, PBN, SIN-1, SNP, AsA, and $\mathrm{NaNO}_{2}$ were $45,100,100,100,100$, and $200 \mu \mathrm{mol} \mathrm{L}^{-1}$, respectively. Protein content was determined 2 days after treatment in the dark. Data are means ( \pm SE) of four replicates of a single typical experiment. Three series of independent experiments were carried out giving reproducible results.

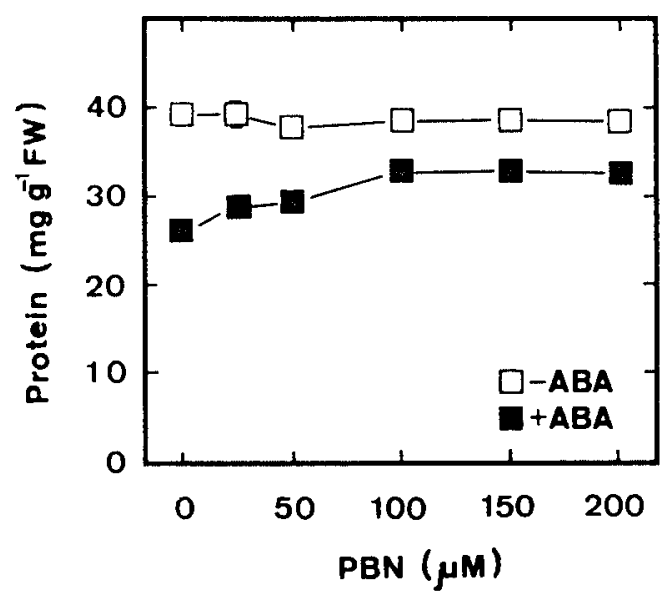

Figure 4. Effect of PBN concentrations on protein contents of rice leaves treated with ABA. Detached rice leaves were treated with either water or $45 \mu \mathrm{mol} \mathrm{L}^{-1} \mathrm{ABA}$ in the dark. Data are means ( $\pm \mathrm{SE}$ ) of four replicates of a single typical experiment. Three series of independent experiments were carried out giving reproducible results.
Table 4. Effect of PBN on protein, $\mathrm{MDA}$, and $\mathrm{H}_{2} \mathrm{O}_{2}$ contents in ABAtreated rice leaves in the presence or absence of C-PTIO

\begin{tabular}{llll}
\hline Treatment & $\begin{array}{l}\text { Protein } \\
\left(\mathrm{mg} \mathrm{g}^{-1} \mathrm{FW}\right)\end{array}$ & $\begin{array}{l}\mathrm{MDA} \\
(\mathrm{nmol} \mathrm{g}\end{array}$ & $\begin{array}{l}\mathrm{H}_{2} \mathrm{O}_{2} \\
(\mu \mathrm{Fmol} \mathrm{g}\end{array}$ \\
\hline $\mathrm{H}_{2} \mathrm{O}$ & $40.2 \pm 1.2$ & $31.6 \pm 0.31$ & $31.2 \pm 1.1$ \\
$\mathrm{ABA}$ & $28.8 \pm 1.5$ & $36.7 \pm 0.40$ & $39.3 \pm 2.4$ \\
$\mathrm{ABA}+\mathrm{PBN}$ & $35.2 \pm 2.8$ & $31.8 \pm 0.56$ & $31.0 \pm 0.96$ \\
$\mathrm{ABA}+\mathrm{PBN}+\mathrm{C}-\mathrm{PTIO}$ & $27.0 \pm 0.56$ & $38.1 \pm 0.72$ & $38.7 \pm 2.2$ \\
\hline
\end{tabular}

The concentrations of ABA, PBN, and C-PTIO were 45, 100, and $100 \mu \mathrm{mol} \mathrm{L}{ }^{-1}$, respectively. Protein, MDA, and $\mathrm{H}_{2} \mathrm{O}_{2}$ contents were determined 2 days after treatment in the dark. Data are means $( \pm S E)$ of four replicates of a single typical experiment. Three series of independent experiments were carried out giving reproducible results.

ABA-promoted leaf senescence was observed to be 100 $\mu \mathrm{mol} / \mathrm{L}$ (Fig. 4).

To investigate whether the protective effect induced by PBN treatment was the result of the production of $\mathrm{NO}, 100 \mu \mathrm{mol} / \mathrm{L}$ c-PTIO, a NO-specific scavenger, was applied along with $100 \mu \mathrm{mol} / \mathrm{L}$ PBN. The effect of PBN on ABA-promoted protein loss and increase in MDA and $\mathrm{H}_{2} \mathrm{O}_{2}$ contents could be reversed by c-PTIO (Table 4). We also observed that PBN counteracted $A B A$-induced increase of activities of antioxidative enzymes (SOD, APOD, GR and CAT) and C-PTIO reversed the effect of PBN-decreased enzyme activities (Table 5). Furthermore, the effect of PBN on ABA-decreased AsA and GSH contents could be reversed by c-PTIO (Table 5). Clearly, the effect of $\mathrm{NO}$ donor PBN is attributable to $\mathrm{NO}$ released.

\section{Discussion}

It has been shown that $\mathrm{ABA}$ can cause an increased production of $\mathrm{H}_{2} \mathrm{O}_{2}$, induce the expression of some antioxidant genes and increase the activities of antioxidative enzymes such

Table 5. Effect of PBN on the activities of antioxidative enzymes and the contents of AsA and GSH in ABA-treated rice leaves in the presence or absence of C-PTIO.

\begin{tabular}{lllllll}
\hline Treatment & CAT & SOD & APOD & GR & AsA \\
(units $\mathrm{mg}^{-1}$ protein) & (units $\mathrm{mg}^{-1}$ protein) & $\begin{array}{l}\mathrm{GSH} \\
\text { (units } \mathrm{mg}^{-1} \text { protein) }\end{array}$ & $\begin{array}{l}\text { (units } \mathrm{mg}^{-1} \text { protein) } \\
\left(\mu \mathrm{mol} \mathrm{g} \mathrm{g}^{-1} \mathrm{FW}\right)\end{array}$ \\
\hline $\mathrm{H}_{2} \mathrm{O}$ & $0.16 \pm 0.00$ & $1.0 \pm 0.03$ & $1.6 \pm 0.08$ & $0.15 \pm 0.01$ & $9.6 \pm 0.29$ & $1.7 \pm 0.16$ \\
$\mathrm{ABA}$ & $0.20 \pm 0.00$ & $1.8 \pm 0.01$ & $2.3 \pm 0.11$ & $0.20 \pm 0.01$ & $7.0 \pm 0.22$ & $0.77 \pm 0.10$ \\
$\mathrm{ABA}+\mathrm{PBN}$ & $0.16 \pm 0.01$ & $1.1 \pm 0.01$ & $1.9 \pm 0.10$ & $0.15 \pm 0.01$ & $11.3 \pm 0.20$ & $1.5 \pm 0.09$ \\
ABA + PBN + C-PTIO & $0.22 \pm 0.01$ & $1.8 \pm 0.01$ & $2.3 \pm 0.17$ & $0.20 \pm 0.01$ & $9.0 \pm 0.36$ & $1.1 \pm 0.09$ \\
\hline
\end{tabular}

The concentrations of ABA, PBN, and c-PTIO were 45, 100, and $100 \mu \mathrm{mol} \mathrm{L}^{-1}$, respectively. Enzyme activities, AsA, and GSH were determined 2 days after treatment in the dark. Data are means $( \pm S E)$ of four replicates of a single typical experiment. Three series of independent experiments were carried out giving reproducible results. 
as SOD, APOD, GR, CAT, and POD in plants (Bueno et al. 1998, Gong et al. 1998, Guan and Scandalios 1998, Guan et al. 2000, Jiang and Zhang 2001, Zhang et al. 2001). These suggest that $A B A$ treatment causes an oxidative stress in plants. Our results not only have shown that $A B A$ increased the content of $\mathrm{H}_{2} \mathrm{O}_{2}$ (Fig. 1) and the activities of SOD, APOD, GR, and CAT (Fig. 2), but also demonstrate that caused a decrease in AsA and GSH contents. Meanwhile, protein loss and lipid peroxidation were observed in ABA-treated rice leaves (Fig. 1). All these results suggest that $A B A$ causes an oxidative stress and that ABA-promoted senescence of rice leaves is mediated through oxidative stress. This suggestion is further supported by the observations that free radical scavengers ( $\mathrm{SB}$ and $\mathrm{GSH}$ ) inhibit $\mathrm{ABA}$-induced senescence, ABA-increased lipid peroxidation and $\mathrm{H}_{2} \mathrm{O}_{2}$ content, ABAincreased antioxidative enzyme activities, and ABA-decreased antioxidants (Tables 1 and 2).

There is only limited information about the mechanism of ABA-induced $\mathrm{H}_{2} \mathrm{O}_{2}$ production. In guard cells, ABA-induced $\mathrm{H}_{2} \mathrm{O}_{2}$ generation is regulated by plasma-membrane NADPH oxidase (Pei at al. 2000, Zhang et al. 2001). Recently, Jiang and Zhang (2002) also reported that plasma-membrane NADPHoxidase is involved in ABA- and water stress-induced antioxidant defense in leaves of maize seedlings. Our unpublished observations indicate that diphenyleneiodonium chloride and imidazole, inhibitors of NADPH oxidase (Cross 1990, Pei et al. 2000), prevented ABA-induced $\mathrm{H}_{2} \mathrm{O}_{2}$ production, ABA-promoted senescence, $A B A$-increased antioxidative enzyme activities and $A B A-d e c r e a s e d$ antioxidants in rice leaves. Similar results were obtained by using dimethylthiourea, a chemical trap for $\mathrm{H}_{2} \mathrm{O}_{2}$ (unpublished data). Here, we show that the increase in $\mathrm{H}_{2} \mathrm{O}_{2}$ content caused by ABA preceded the decrease in protein content and increase in MDA content (Fig. 1). It appears that $\mathrm{H}_{2} \mathrm{O}_{2}$ is a key signaling molecule involved in ABA-induced senescence of rice leaves.

It has been suggested that $\mathrm{NO}$ is an antioxidant in plants and its action may be explained by its ability to scavenge AOS (Beligni and Lamattina 1999 a, b, 2002, Cheng et al. 2002, Hung et al. 2002). If NO acts as an antioxidant, NO may reduce $A O S$ levels in $A B A$-treated rice leaves. Since $\mathrm{H}_{2} \mathrm{O}_{2}$ is involved in $\mathrm{ABA}$-induced senescence of rice leaves (Fig. 1 and unpublished data) and $\mathrm{NO}$ reduces $\mathrm{ABA}$-increased $\mathrm{H}_{2} \mathrm{O}_{2}$ content (Table 4), it appears that $\mathrm{NO}$ indeed has the ability to scavenge AOS.

In the present investigation, we found that $\mathrm{NO}$ reduced ABA-increased MDA content and antioxidative enzyme activities (Tables 4 and 5) in rice leaves. These results are in agreement with our previous work, in which we demonstrated that NO counteracted paraquat-increased MDA content and antioxidative enzyme activities (Hung et al. 2002). Because lipid peroxidation and the increase in antioxidative enzyme activities are the consequence of AOS overproduction (Kellogg and Fridovich 1975, Thompson et al. 1987) and NO acts as an AOS scavenger, therefore, the reduction of MDA content and antioxidative enzyme activities could be a result of low levels of $\mathrm{H}_{2} \mathrm{O}_{2}$ in rice leaves treated with $\mathrm{NO}$ and $A B A$. The fact that $\mathrm{NO}$ counteracts $\mathrm{ABA}$-decreased $\mathrm{AsA}$ and $\mathrm{GSH}$ (Table 5) would result in the capacity of $\mathrm{NO}$ to scavenge $\mathrm{H}_{2} \mathrm{O}_{2}$ in rice leaves treated with $\mathrm{NO}$ and $\mathrm{ABA}$ compared to rice leaves treated with $\mathrm{ABA}$ alone and might account in part for the lower contents of $\mathrm{H}_{2} \mathrm{O}_{2}$ observed in rice leaves treated with $\mathrm{NO}$ and $\mathrm{ABA}$ (Table 4).

CAT, APOD, and POD have been shown to be directly inhibited by NO (Ferrer and Barceló 1999, Clark et al. 2000). However, our results show that PBN treatment alone did not affect antioxidative enzyme activities in rice leaves (data not shown). Thus, the reduction of ABA-induced increase in antioxidative enzyme activities by $\mathrm{NO}$ is unlikely due to a direct NO-mediated inhibition of the enzymes.

In animals, NO on one side displays cytotoxic activity and on the other side may play a cytoprotective role in oxidative stress (Kroncke et al. 1997). AOS can react with NO to form peroxynitrite (Kim and Han 2000, Martinez et al. 2000). Peroxynitrite is often thought to have cytotoxic effect (Huie and Padmaja 1993, Alamillo and Garcia-Olmedo 2001, Beligni and Lamattina 2001). Proxynitrite has been shown to react with $\mathrm{H}_{2} \mathrm{O}_{2}$ to yield nitrite ion and oxygen (Martinez et al. 2000). This reaction has been suggested to be the mechanism of NO cytoprotective actions in animals (Wink et al. 1993). Based on our results, it appears that this mechanism is operating in rice leaves.

In rice leaves, we have shown that NO counteracts oxidative stress induced by paraquat, dehydration, and polyethylene glycol (Cheng et al. 2002, Hung et al. 2002). Herein, we observed that $\mathrm{NO}$ donors act similarly as free radical scavengers ( $\mathrm{SB}$ and $\mathrm{GSH}$ ) in inhibiting $\mathrm{ABA}$-promoted rice leaf senescence. All these results strongly suggest that antioxidant properties of $\mathrm{NO}$ are operating for counteracting oxidative stress in rice leaves.

Acknowledgements. This work was supported by grant NSC 902313-B-002-267 from the National Science Council of the Republic of China.

\section{References}

Alamillo JM, Garcia-Olmedo F (2001) Effect of urate, a natural inhibitor of peroxynitrite mediated toxicity, in the response of Arabidopsis thaliana to the bacterial pathogen Pseudomones syringae. Plant $J$ 25: 529-540

Beligni MV, Lamattina L (1999 a) Nitric oxide counteracts cytotoxic processes mediated by reactive oxygen species in plant tissues. Planta 208: 337-344

Beligni MV, Lamattina L (1999 b) Nitric oxide protects against cellular damage produced by methyl violgen herbicides in potato plants. Nitric Oxide Biol Chem 3: 199-208

Beligni MV, Lamattina L (2000) Nitric oxide stimulates seed germination and de-etiolation, and inhibits hypocotyls elongation, three light-inducible responses in plants. Planta 210: 215-221

Beligni MV, Lamattina $L$ (2001) Nitric oxide in plants: the history is just beginning. Plant Cell Environ 24: 267-278 
Beligni MV, Lamattina L (2002) Nitric oxide interferes with plant photooxidative stress by detoxifying reactive oxygen species. Plant Cell Environ 25: 737-748

Beligni MV, Fath A, Bethake PC, Lamattina L, Jones RL (2002) Nitric oxide acts as an antioxidant and delays programmed cell death in barley aleurone layers. Plant Physiol 129: 1462-1650

Bradford MM (1976) A rapid and sensitive method for the quantitation of microgram quantities of protein utilizing the principle of proteindye binding. Anal Biochem 72: 248-254

Bueno P, Piqueras A, Kurepa J, Savouré A, Verbruggen N, Van Montagu M, Inzé D (1998) Expression of antioxidant enzymes in response to abscisic acid and high osmoticum in tobacco BY-2 cell cultures. Plant Sci 138: 27-34

Cheng F-Y, Hsu S-Y, Kao CH (2002) Nitric oxide counteracts the senescence of detached rice leaves induced by dehydration and polyethylene glycol but not by sorbitol. Plant Growth Regul 38: 265-272

Chu C, Lee TM (1989) The relationship between ethylene biosynthesis and chilling tolerance in seedlings of rice (Oryza sativa). Bot Bull Acad Sin 30: 263-273

Clark D, Dunar J, Navarre DA, Klessig DF (2000) Nitric oxide inhibition of tobacco catalase and ascorbate peroxidase. Mol Plant-Microbe Interact 13: 1380-1384

Creelman RA (1989) Abscisic acid physiology and biosynthesis in higher plants. Physiol Plant 75: 131-136

Cross AR (1990) Inhibitors of leukocyte superoxide generating oxidase: mechanisms of action and methods for their elucidation. Free Radic Biol Med 8: 71-93

Delledonne M, Xia Y, Dixon RA, Lamb C (1998) Nitric oxide functions as a signal in plant disease resistance. Nature 394: 585-588

d'Ischia M, Palumbo A, Buzzo F (2000) Interactions of nitric oxide with lipid peroxidation products under aerobic conditions: Inhibitory effects on the formation of malondialdehyde and related thiobabituric acid-reactive substances. Nitric Oxide Biol Chem 4: 4-14

Ferrer MA, Barceló AR (1999) Differential effects of nitric oxide on peroxidase and $\mathrm{H}_{2} \mathrm{O}_{2}$ production by the xylem of Zinnia elegans. Plant Cell Environ 22: 891-897

Foster JG, Hess JL (1980) Responses of superoxide dismutase and glutathione reductase activities in cotton leaf tissue exposed to an atmosphere enriched in oxygen. Plant Physiol 66: 482-487

Foyer CH, Lopez-Delgado H, Dat JF, Scott IM (1997) Hydrogen peroxide and glutathione-associated mechanism of acclimatory stress tolerance and signaling. Physiol Plant 100: 241-254

Furchgott RF (1995) Special topic: nitric oxide. Annu Rev Physiol 57: 659-682

Garcia-Mata C, Lamattina L (2002) Nitric oxide and abscisic acid cross talk in guard cells. Plant Physiol 128: 790-792

Gepstein S, Thimann KV (1980) Changes in the abscisic acid content of oat leaves during senescence. Proc Natl Acad Sci USA 77: 2050-2053

Gong M, Li YJ, Chen SZ (1998) Abscisic acid-induced thermotolerance in maize seedlings is mediated by calcium and associated with antioxidant systems. J Plant Physiol 153: 488-496

Guan L, Scandalios JG (1998) Effects of the plant growth regulator abscisic acid and high osmoticum on the developmental expression of the maize catalase genes. Physiol Plant 104: 413-422

Guan L, Zhao J, Scandalios JG (2000) Cis-elements and trans-factors that regulate expression of the maize Cat1 antioxidant gene in response to $A B A$ and osmotic stress: $\mathrm{H}_{2} \mathrm{O}_{2}$ is the likely intermediary signaling molecule for the response. Plant J 22: 87-95
Heath RL, Packer L (1968) Photoperoxidation in isolated chloroplasts I. Kinetics and stoichiometry of fatty acid peroxidation. Arch Biochem Biophys 125: 189-198

Huie RE, Padmaja S (1993) The reaction of $\mathrm{NO}$ with $\mathrm{O}_{2}{ }^{-}$. Free Radic Res Commun 235: 264-267

Hung KT, Chang CJ, Kao CH (2002) Paraquat toxicity is reduced by nitric oxide in rice leaves. J Plant Physiol 159: 159-166

Jana S, Choudhuri MA (1981) Glycolate metabolism of three submerged aquatic angiosperm during aging. Aquat Bot 12: 345-354

Jiang M, Zhang J (2001) Effect of abscisic acid on active oxygen species, antioxidative defense system and oxidative damage in leaves of maize seedlings. Plant Cell Physiol 42: 1265-1273

Jiang M, Zhang J (2002) Involvement of plasma membrane NADPH oxidase in abscisic acid- and water stress-induced antioxidant defense in leaves of maize seedlings. Planta 215: 1022-1030

$\mathrm{Kao} \mathrm{CH}$ (1980) Senescence of rice leaves IV. Influence of benzyladenine on chlorophyll degradation. Plant Cell Physiol 21: 1255-1262

Kato M, Shimizu S (1987) Chlorophyll metabolism in higher plants. VII. Chlorophyll degradation in higher pants. VII. Chlorophyll degradation in senescing tobacco leaves: Phenolic-dependent peroxidative degradation. Can J Bot 65: 729-735

Kellogg EW, Fridovich I (1975) Superoxide, hydrogen peroxide, and singlet oxygen in lipid peroxidation by xanthine oxidase system. J Biol Chem 250: 8812-8817

Kende H, Zeevarrt JAD (1997) The five classical plant hormones. Plant Cell 9: 1197-1210

Kim YS, Han S (2000) Nitric oxide protects Cu, Zn-superoxide dismutase from hydrogen peroxide-induced inactivation. FEBS Lett 479: $25-28$

Klessig DF, Durner J, Noad R, Navarre DA, Wendehenne D, Kumar D, Zhou JM, Shah J, Zhaud S, Kachroo P, Trifa Y, Pontier D, Lam E, Silva $H$ (2000) Nitric oxide and salicylic acid signaling in plant defense. Proc Natl Acad Sci USA 97: 8849-8855

Kroncke K-D, Fehsel K, Kolb-Bachofen V (1997) Nitric oxide: Cytotoxicity versus cytoprotection - how, why, when, and where? Nitric Oxide Biol Chem 2: 107-120

Laws MY, Charles SA, Halliwell B (1983) Glutathione and ascorbic acid in spinach chloroplasts: the effect of hydrogen peroxide and of paraquat. Biochemical J 210: 899-903

Leshem YY (2000) Nitric Oxide in Plants. Occurrence, Function and Use. Kluwer Academic Publishers, Dordrecht

Leshem YY, Haramaty E (1996) Plant aging: the emission of NO and ethylene and effect of NO-releasing compounds on growth of pea (Pisum sativum) foliage. J Plant Physiol 148: 258-263

MacAdam JW, Nelson CJ, Sharp RE (1992) Peroxidase activity in the leaf elongation zone of tall fescue. Plant Physiol 99: 872-878

Martinez GR, DiMascio P, Bonini MG, Augusto O, Briviba K, Sies H, Mauer P, Röthlisberger U, Herold S, Koppenol WH (2000) Peroxynitrite does not decompose to singlet oxygen $\left({ }^{\prime} \Delta g \mathrm{O}_{2}\right)$ and nitroxyl $\left(\mathrm{NO}^{-}\right)$. Proc Natl Acad Sci USA 97: 10307-10312

Nakano Y, Asada K (1981) Hydrogen peroxide is scavenged by ascorbate-specific peroxidase in spinach chloroplasts. Plant Cell Physiol 22: $867-880$

Neill SJ, Desikan R, Clarke A, Hancock JT (2002) Nitric oxide is a novel component of abscisic acid signaling in stomatal guard cells. Plant Physiol 128: 13-16

Nooden LD (1988) Abscisic acid, auxin and other regulators of senescence. In: Nooden LD (ed) Senescence and Aging in Plants. Academic Press Inc., San Diago pp 329-368 
Noritake T, Kawakita K, Doke N (1996) Nitric oxide induces phytoalexin accumulation in potato tuber tissues. Plant Cell Physiol 37: 113 116

O'Donnel VB, Chunley PH, Hogg N, Bloodsworth A, Darley-Usmar VM, Freeman BA (1997) Nitric oxide inhibition of lipid peroxidation: Kinetics of reaction with lipid peroxyl radicals and comparison with $\alpha$-tocopherol. Biochemistry 36: 15216-15223

Pagnussat GC, Simontacchi M, Puntarulo S, Lamattina L (2002) Nitric oxide is required for root organogenesis. Plant Physiol 129: 954 956

Paoletti F, Aldinucci D, Mocali A, Capparini A (1986) A sensitive spectrophotometric method for the determination of superoxide dismutase activity in tissue extracts. Anal Biochem 154: 536-541

Pedroso MC, Magalhases JR, Durzan D (2000) Nitric oxide induces cell death in Taxus cells. Plant Sci 157: 173-180

Pei ZM, Murata N, Benning G, Thomine S, Klüsener B, Allen GJ, Grill E, Schroeder JI (2000) Calcium channels activated by hydrogen peroxide mediate abscisic acid signaling in guard cells. Nature 406: 731-734

Scherer GFE, Holk A (2000) NO donors mimic and NO inhibitors inhibit cytokinin action in betaine accumulation in Amaranthus caudatus. Plant Growth Regul 32: 345-350
Seo M, Koshiba T (2002) Complex regulation of ABA biosynthesis Trends Plant Sci 7: 41-48

Smith IK (1985) Stimulation of glutathione synthesis in photorespiring plants by catalase inhibitors. Plant Physiol 79: 1044-1047

Strother S (1988) The role of free radicals in leaf senescence. Gerontology 34: 151-156

Taylor LB, Burbridge A, Thompson AJ (2000) Control of abscisic acid synthesis. J Exp Bot 21: 1563-1574

Thompson JE, Legge RL, Barber RF (1987) The role of free radical in senescence and wounding. New Phytol 105: 317-344

Walker-Simmons M (1987) ABA levels and sensitivity in developing wheat embryos of sprouting resistant and susceptible cultivars. Plant Physiol 84: 61-66

Wink DA, Hanbauer I, Krishna MC, DeGraff W, Gamson J, Mitchell JB (1993) Nitric oxide protects against cellular damage and cytotoxicity from reactive oxygen species. Proc Natl Acad Sci USA 90: 9813-9817

Yang J, Zhang J, Wang Z, Zhu Q, Liu L (2002) Abscisic acid and cytokinins in the root exudates and leaves and their relationship to senescence and remobilization of carbon reserves in rice subjected to water stress during grain filling. Planta 215: 645-652

Zhang X, Zhang L, Dong F, Gao J, Galbraite DW, Song C-P (2001) Hydrogen peroxide is involved in abscisic acid-induced stomatal closure in Vicia faba. Plant Physiol 126: 1438-1448 